\title{
An evaluation of Global Management Accounting Principles in the sustainability of a South African mechanised piggery
}

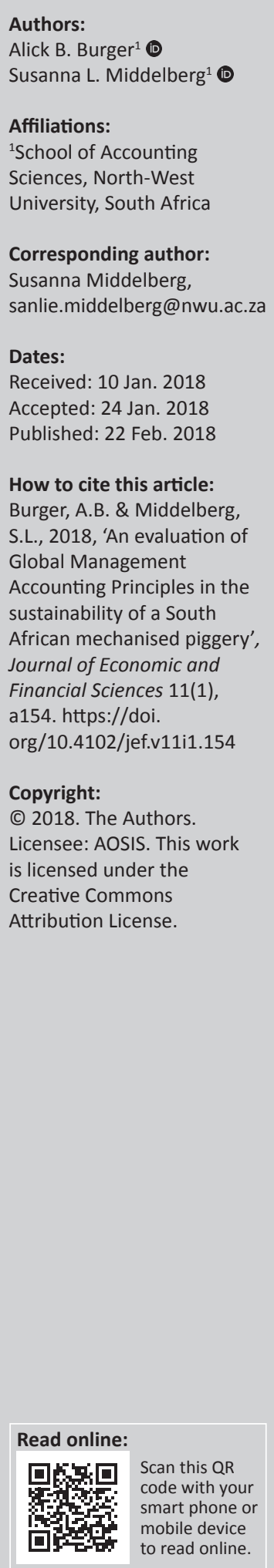

Research purpose: The aim of this article was to evaluate the relevance of Global Management Accounting Principles (GMAPs) in the sustainability of a mechanised piggery in a South African context.

Motivation for the study: Considering the pressure which commercial agriculture in South Africa is experiencing, as well as the growing nature of pork production in this sector, mechanised piggeries would have to consider ways in which to manage their operations in order to remain sustainable.

Research approach, design and method: The research design took the form of an exploratory case study and contextual applied research with an inductivist approach to qualitative research.

Main findings: The findings include that, without pre-knowledge of GMAPs, Piggery A employed a large number of the concepts and principles described by GMAPs as best practice.

Practical and managerial implications: All commercial farming operations should consider GMAPs as a tool to establish best practice in the support of decision-making that promotes sustainability of farming operations.

Contribution or value-add: The article's contribution is to highlight that GMAPs can also be utilised as an effective decision-making tool in a mechanised piggery albeit it was designed for use in large corporations.

\section{Introduction}

It is becoming increasingly difficult to make sound business decisions that support business sustainability in the ever-increasingly volatile, uncertain, complex and ambiguous (VUCA) environment in which a business has to operate (Chartered Institute of Management Accountants [CIMA] 2016). Management accounting is concerned with the supply of information to support or assist sound business decision-making, ensuring value creation for stakeholders through business progress and organisational change (Figge \& Hahn 2013; Gimzauskiene \& Valanciene 2008; Masztalerz 2014). The importance of sound business decision-making was recently highlighted by the Association of International Certified Professional Accountants (The Association) - 'Quality decision-making has never been more important - or more difficult' [CIMA \& American Institute of Certified Public Accountants (AICPA) 2014]. The Association published the first set of Global Management Accounting Principles ${ }^{\odot}$ (GMAPs) in 2014.

Furthermore, sustainability is regarded as a driver for both risks and opportunities in business (Schaltegger 2011). It is posited that management accounting plays a key role by addressing the identified risks and opportunities associated with sustainability (Bui \& de Villiers 2017; Schaltegger 2011).

Commercial farmers in South Africa are facing many influential factors over which they can exert little or no control. The sustainability of commercial farming in South Africa requires a fresh look at available tools to steer farming through uncertainty and instability. Farming operations, as any other business, should be able to master the skill of sound business decision-making to ensure sustainability of the operation. This is true for the commercial agricultural industry globally, but

Note: This article is partially based on the author's thesis of the degree of Magister Commercii in Management Accountancy at the Potchefstroom Campus of the North-West University, South Africa, with supervisor Prof S. Middelberg, received November 2016, available here: http://dspace.nwu.ac.za/bitstream/handle/10394/24860/Burger_AB_2016.pdf?isAllowed=y\&sequence=1 
specifically for the industry in South Africa. The South African commercial agriculture sector is facing a VUCA environment with inter alia dismal local and international economic growth, local policy uncertainty and global competition. Successful commercial farmers have to make sound business decisions that would support biologically sustainable farming practices.

The aim of this article is to explore whether GMAPs are relevant to a commercial farming operation, and if relevant, whether they could add to the sustainability of such an operation. A mechanised piggery was utilised as a case study. The contribution of this study is to highlight whether GMAPs can also be utilised as an effective decision-making tool in a mechanised piggery, albeit it was designed for use in large corporations.

The Association is a partnership between the AICPA and CIMA and forms the largest body of management accountants globally (CIMA \& AICPA 2014). Global Management Accounting Principles describe the constituents of an effective management accounting function, including competent people, clear principles and well-managed performance applied across 14 practice areas (CIMA \& AICPA 2014).

The four headline principles of GMAPs are (1) communication that provides influential insight, (2) relevant information, (3) impact on value is analysed and (4) stewardship builds trust. The GMAPs provide a foundation for effective decisionmaking (CIMA 2016).

The rest of the article is structured as follows: firstly, it provides an overview of the literature review that was conducted, followed by a presentation of the empirical research methodology of the study. The results of the study and the implications thereof are discussed next, followed by some concluding comments. Lastly, the limitations of this study and areas for further research are identified.

\section{Literature review}

Commercial farming forms the backbone of food security in most countries, especially in South Africa. Moreover, it is evident that agriculture is still one of the most labourintensive sectors and source of employment in the South African economy (Ariatti \& Chasomeris 2015), where more than $6.3 \%$ of total employment is provided within the agricultural, hunting, forestry and fishing sectors (Department of Agriculture, Forestry and Fisheries [DAFF] 2016). The agricultural industry globally, but specifically in South Africa, is besieged by complexities which include matters of (1) mechanisation (Gan-Mor, Clark \& Upchurch 2007; Saayman \& Middelberg 2014), (2) taxation (Darroch, Lee \& Ortmann 2008), (3) political influences (Agri South Africa 2015; Lichfield 2015; Mokhema 2015; Nkosi 2015; Visser 2015) and (4) market-related forces (Hamilton 2006; Lichfield 2015; Visser 2015).
Pork production forms part of commercial agriculture and contributes to the total envelope of industries within the agricultural sector (DAFF 2016; Munzhelele et al. 2017). DAFF (2016) recorded the pork production industry as part of the larger animal production segment within the agricultural sector. In 2014 and 2015, the animal production group had an estimated gross value of almost R110 billion. Pork production grew in gross value from a mere R1 billion in 2001 and 2002 to an estimated R5 billion in 2014 and 2015 (DAFF 2016). This effectively means that the gross value of pork production increased with $442 \%$ over a period of 13 years. The animal production segment grew with 334\% in gross value over the same period.

Considering the pressure which commercial agriculture in South Africa is experiencing, as well as the growing nature of pork production in this sector, mechanised piggeries would have to consider ways in which they can manage their operations in order to remain sustainable.

In the past, management accounting had been stereotyped in terms of cost accounting, and specifically cost allocation. This is evident in the large range of literature that focuses on the implementation of, inter alia, activity-based costing $(\mathrm{ABC})$ models in various industries and recommendations for the use of $A B C$ and other cost accounting systems for the improvement of decision-making (Bibbey 1995; Holloway 2004; Joubert 1996; M.L. Joubert, pers. comm., 23 July 2015; Konan 2013; Le Roux 1982; Middelberg 2007; Reynolds \& Van der Poll 2015; Rundora, Ziemerink \& Oberholzer 2013; Savic, Vasiljevic \& Dordevic 2014; Van der Linde 2011). However, before any operation can embark on a journey to implement an advanced cost accounting system, such as the $\mathrm{ABC}$ system, the operation must consider the fundamentals of an ABC system - which would include principles within GMAPs.

Typical to these research studies is discussion of the core elements that make up the principles underlying any $A B C$ model. Le Roux (1982) studied the cost of producing sultana grapes in the Upington area in the Northern Cape province of South Africa. Although Le Roux's findings may be relevant to agriculture, they date back to more than 30 years. As both the economic and agricultural environments have since been changed, the relevance of such a research for today can be questioned.

Other literature (Bibbey 1995; Joubert 1996; Middelberg 2007) is about specialised research into a specific business in an industry. This leaves the question whether the models are still used to this day (M.L. Joubert, pers. comm., 23 July 2015). Furthermore, these studies did not focus on commercial farming operations.

Savic et al. (2014) argued that agri-businesses in Serbia should focus on strategic cost management strategies, which rely on strategic cost analysis. They discussed various advanced forms of costing systems such as $\mathrm{ABC}$, target costing and lean 
costing, amongst others. All of these systems, however, require various considerations before being selected for use (Savic et al. 2014). The critique against this study is that it did not address the requirements needed for sophisticated cost accounting systems to be successfully implemented. The study only made suggestions towards advanced cost accounting systems, which Konan (2013) found in his study to be problematic because of the complexity of specifically the ABC system.

Notwithstanding, a study conducted by Holloway (2004) that addressed management accounting principles of a black economic empowerment (BEE) project on an apple farm in the Free State can be considered as closely related to the intended research study. Holloway's study considered a workable system revolving around the use of information technology (IT) and management principles. It focussed on the perceived relevance and benefits of the implementation of an IT system and the information that the system produced in relation to management principles. The study indicated that, on average, $73 \%$ of the respondents found that the IT system had achieved the overall objective. However, the timing of the study is similar to other studies, older than 10 years and specifically focussed on an apple farm within the BEE context.

The notion therefore is that research in management accounting is generally different for each case. This is reiterated by Luft and Shields (2003) who stated that if management accounting had the same effect on all individuals, then there would be no need to consider individuals per se in management accounting research. However, the same management accounting often has different effects on different individuals (Luft \& Shields 2003).

It is therefore important for any business to take a proverbial step back and observe the foundation that an advanced cost allocation system requires before embarking on a process of implementation. This implies that the business should have a thorough understanding of management accounting principles.

A research was conducted by Masztalerz (2014) to critically look at and discuss the consultation draft on GMAPs launched in 2014. The findings of this study argued that the GMAPs are not a neutral set of principles that can commonly be accepted, but rather a subjective view on management accounting. The research furthermore posited that the creators of GMAPs might have hidden interests with the publication thereof.

To this end, the GMAPs were published in 2014 and no further literature on the subject, specifically applied to commercial agriculture in general or in a specific case, could be found.

Smith (2014) stated that the proposed principles are designed to ensure that management accountants provide the right people with the right information at the right time, to ensure that they make the best decisions about their organisation's long-term success.

Smith (2014) further referred to the emergence of countries from the worst recession since the Second World War and highlighted that when businesses fail, society as a whole suffers. It can be said that this is just as relevant to an agricultural business as to any other sector's business. Smith also referred to internal audit, corporate governance and regulation having a role to play in improving business conduct, but this is equally true about management accounting. A commercial farming operation can therefore also gain as much advantage from management accounting as any other business operation in any other sector.

It can therefore be concluded that as management accounting principles in the form of GMAPs are relevant, so is the production of pork on a commercial scale. Combining these two actual topics against the backdrop of the larger environment in which agriculture operates is the problem which this article intends to address.

\section{Defining business sustainability}

The concept of sustainability was made famous by Brundtland (1989) in her speech addressing climate change. Sustainability stems from the word 'sustain', which means to manage to make something continue to exist over a long period of time - according to Dignen (2000).

Chartered Institute of Management Accountants, AICPA and Chartered Professional Accountants of Canada (CPA) (2013) cited that there is research evidence about businesses placing more emphasis on sustainability because it (1) has a positive effect on their profitability, (2) improves employee engagement and participation and (3) positively affects the establishment of relationships with suppliers and customers. Ten key elements within three broad categories were described in their publication, which focused on long-term, forward-looking practices (CIMA et al. 2013) to keep organisations going for future generations. This agrees with the definition of sustainability according to Dignen (2000).

The King Committee (2009) defined sustainability by citing principles from the reformed United Kingdom corporate legislation. In its opinion, sustainability is concerned with taking an appropriate long-term perspective, actively building successful relationships with employees and those in the supply chain, and lastly taking the responsibility towards ethical practices - and their impact on social and environmental aspects of society - seriously (King Committee 2009).

Business sustainability can therefore be defined as the management process of taking a long-term, forward-looking perspective, actively building stronger relationships with the various stakeholders to ensure that the business continues to exist for future generations. 


\section{Research methodology}

The empirical research assumed the form of a contextual and exploratory case study. Empirical data collection consisted of a semi-structured interview with Owner A (the owner of the case study) of Piggery A (the case study). The questions were designed to enable the researcher to perform a gap analysis to determine which elements of GMAPs are already in place at Piggery A and which elements require consideration.

This article embarked from an interpretivism paradigm because of the nature of the research. From that perspective, the researcher could not be separated from the data collected and had thus been required to interpret the data. The use of an exploratory case study and a semi-structured interview supported this paradigm from a methodological and a design perspective, respectively.

Researchers have used case study research for many years across various fields or disciplines, all in an effort to answer the 'how' and the 'why' questions (Nieuwenhuis 2014). Yin (2014) reiterated that a case study research allows an understanding of complex social phenomena.

Before the study was formally undertaken, the researcher had engaged with Owner A about the research, its aim and content. This ensured that the key individual to the study's data collection process (Nieuwenhuis 2014) had a high level of buy-in and willingness to participate constructively in the research.

During the design phase of the study, before the appointed interview was taken place, the predetermined set of questions was shared with Owner A. In the built-up to the interview, the researcher and Owner A communicated via telephone and email on a regular basis. It was clear that Owner A's intricate knowledge of Piggery A since inception would suffice for the collection of rich data to saturate the article's data needs, and therefore only Owner A was interviewed. At one point during the interview, Owner A involved the professional accountant of Piggery A to assist with the evaluation of GMAPs in the farm.

The interview and field visit took place over a period of 2 days on the farm where Piggery A is being operated. The interview itself took place with intervals spread over the 2 days. Two formal interview sessions of approximately $2 \mathrm{~h}$ each were conducted and held in the comfort of Owner A's personal residence. This ensured that Owner A was at his leisure and it facilitated the process of achieving the keys to a successful interview.

During the interview, the researcher made field notes while the conversation was being recorded. Owner A had the opportunity to review some of the notes taken down and he answered some follow-up questions. During the 2-day field visit, the researcher could also physically observe the operation of Piggery A and photographs of the pig steads were taken. The final field report and the recordings of the interview were shared with Owner A to ensure quality and validity of the article.

\section{Background of Piggery A}

The object of the article was a commercial farming operation in South Africa that has a focus on pork production, that is, Piggery A. It is a sole proprietor-type business entity managed and owned by Owner A.

Owner A bought the farm on which Piggery A is currently situated in 1968. This was also the year when the first pig stead was raised. The farming operation of Piggery A (refer to Figure 1) was established within a diverse farming operation which ranged from the planting and harvesting of maize to that of peanuts, amongst others. It was only after Owner A started researching and applying scientific farming practices that the land yielded increased returns. This enabled the farming operation to grow. The piggery was built using scientific principles to ensure optimum health of the sows and the piglets. The diverse farming operation grew and was extended with cattle farming in 1974 and dairy in 1982. Growth came with the procurement of additional farms in the area where the cattle farming continued and the dairy was raised. During the time of the interview, Owner A had almost 600 sows.

The empirical data were collected through a series of semistructured interviews conducted at Piggery A, using the diagnostic checklist for GMAPs as a foundation. CIMA and AICPA (2015) published a diagnostic checklist as a tool to assess the effectiveness of an organisation's management accounting function. The checklist is made up of three sections that must be read in conjunction with the published GMAPs document (CIMA \& AICPA 2015).

The first section of the checklist focuses on the principles and the people, assessing how the organisation's management accounts and larger function interact with the four principles of GMAPs.

The second section provides questions for assessing the organisation's performance management system in addressing the four principles of GMAPs. To achieve sustainable success,

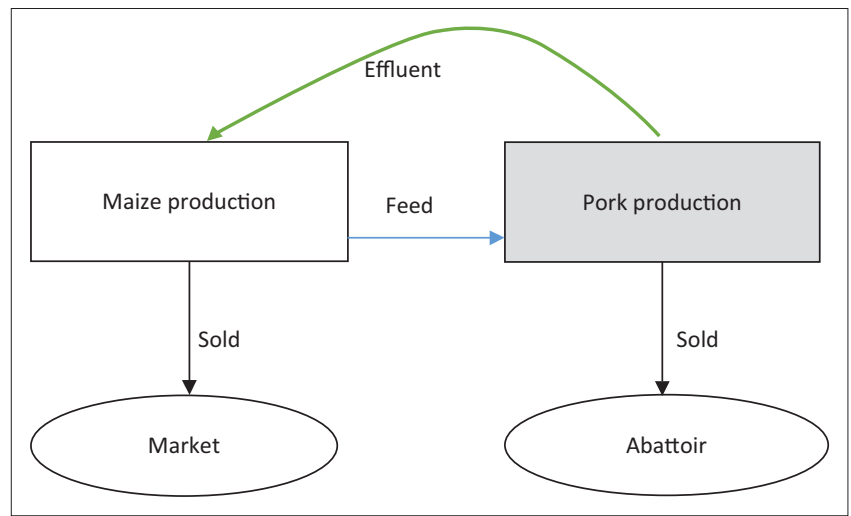

FIGURE 1: Farming operation of Piggery A. 
the managing stakeholders of an organisation have to ensure that performance management develops, deploys and refines the execution of strategy (CIMA \& AICPA 2015).

The final (third) section of the checklist aims to assess the contribution of the organisation's management accounting function towards each of the 14 practice areas, or key activities, that the principles of GMAPs associate with a successful management accounting function.

Except for the final section of the checklist, all questions require a binary answer either in the affirmative or in the negative. A semi-structured approach to the checklist would provide an opportunity for elaboration of the answer to the question (Nieuwenhuis 2014). It appears that the diagnostic checklist is designed to cater for large, multinational companies, and because Piggery A is a sole proprietor- type business, it may not have as many formal structures, functions and practice areas as addressed by the diagnostic checklist. Therefore, the use of a semistructured approach to the interview would provide insight into what is actually applicable to a sole proprietor agribusiness, given the difference in dynamics between a formal, legal entity and an informal, owner-managedtype entity.

All three sections of the diagnostic checklist for GMAPs were answered. During the interview, follow-up questions were posed by the researcher to 'crystallise' certain answers from Owner A on the diagnostic checklist. Some answers led to further questions which brought the discovery of some surprising elements to the fore, such as the motivation for the decision to discontinue pork production at Piggery A.

\section{Results and their implications}

This literature study highlighted that research in the field of management accounting is dominated by the application and evaluation of complex cost allocation systems such as $\mathrm{ABC}$, with studies investigating such systems within the agricultural sector. Problems were, however, experienced with the implementation and maintenance of $A B C$, which lead to the conclusion that businesses should take a step back and first look at applying the basics correctly before embarking on implementing complex cost allocation systems such as ABC.

The results of the empirical study emphasised that the agricultural sector in South Africa finds itself at a pinnacle point, facing major obstacles. It was therefore appropriate to argue that commercial agriculture needs a new tool to assist operations in navigating the complexity of today's economic circumstances. Global Management Accounting Principles are proposed as a solution to this phenomenon. Combined with the challenges the agricultural sector is facing, and the fact that no research on the applicability of GMAPs had been conducted on the sector before, it was found appropriate to conduct a qualitative exploratory research case study with Piggery A.
Owner A realised, already at the early stages of the farming operation, that management information is crucial to a successful farming operation and furthermore that management information is not limited to financial information. The researcher was given access to the management information utilised by the farming operation. The information included inter alia soil content analysis and maize leaf analysis to ascertain the needs of the plants and farm as scientific as possible. These analyses translate into remedying actions to be taken in the form of additives, such as agriculture lime or 'soft' phosphates, to be provided to the soil.

Being an exploratory research case study, it was discovered that GMAPs had a surprisingly strong presence within Piggery A, without any of the key stakeholders having prior knowledge thereof. This discovery leads to the conclusion that if GMAPs can be practised in a sole proprietor farming operation, it can also be practised within more complex farming operations within legal entity business forms, such as companies.

Keeping the definition of sustainability in mind, it can be concluded that the 48-year-old farming operation has been operating sustainably, from a financial perspective, to date. If one observes the farming technologies and practices employed, it could reasonably be argued that these practices contribute to sustainable farming. The integration of the various farming activities and the recycling of waste products in a sustainable manner support this notion.

Regardless of the fact that Owner A decided to discontinue pork production at Piggery A, GMAPs were evaluated as being supportive to the sustainability of Piggery A, having operated since 1968 utilising principles described by GMAPs. It supports the recommendation that GMAPs should be considered as a tool for establishing best practice in commercial farming operations, given its wide applicability.

From the results, it is evident that without pre-knowledge of the content of GMAPs, Piggery A has employed a large number of concepts and principles described by GMAPs as best practice. The farming operation was assessed as being sustainable, given its integrated operating activities completing a circle which can be sustained physically. The descriptions of a number of principles were found not to be applicable to the business-form in which Piggery A operates. However, the underlying principles, such as the assessment of internal controls with the internal audit function, could be adopted in an informal approach to further add value to the farming operation.

Despite the strong presence of principles of GMAPs in Piggery A, external factors (discussed under the 'General observations' section) informed Owner A to discontinue the production of pork over a period of time.

\section{General observations}

Many of the questions of the diagnostic checklist have been specifically formulated to assist organisations with formal 
structures such as companies. A function like internal audit has little to no use for an informal business structure such as a sole proprietor or an owner-managed private company. Notwithstanding, there could be principles embedded in the practice area of internal audit which is applicable across all business forms. Internal controls could assume many forms in different businesses. For example, Owner A has ensured that he is always aware of Piggery A's bank balance. This provides assurance that no expense is paid without his knowledge or that he is at least alerted about the expenses paid which he should investigate.

The most unexpected discovery made during the interview was that Owner A has decided to discontinue the pork production operation by end of December 2016. When asked to explain what led him to this decision, four factors were suggested as the definitive considerations:

1. The effect of the African Growth and Opportunity Act (AGOA) Trade Agreement between South Africa and the United States of America (US) concluded during the course of 2016.

2. Mega-farming operations such as the one filmed by Dreyer (2016)

3. Piggery A's losses made over the last 3 years.

4. South Africa's expected economic growth of close to $0 \%$.

\section{African Growth and Opportunity Act Trade Agreement}

The first factor was described as the pivotal factor in the decision to stop the pork production. According to Owner A, about 40 tons of pork, already processed in manageable portions, is imported to South Africa from the USA on a continuous basis. This is done at a reduced price as compared to the market. Piggery A's production cost is higher than the prevailing market price and as such the piggery became unprofitable.

\section{Mega-farming operations}

The presence of what is termed as 'mega-farming' operations, such as the farming operation described in the Afrikaans television series Megaboere on the KykNET channel (Dreyer 2016), further informed Owner A's decision. Owner A described two such farming operations of which one is a developed-economy-sponsored project to build a 5000-sow unit in the same area as Piggery A as a BEE project. He estimated the cost of such a unit to be about R250 million. This is a scale that Piggery A will not obtain by organic growth.

The farming operation which Dreyer (2016) documented (referred to as Piggery M), as another example, produces $20 \%$ of the South African market's pork and has a 25\% market share of the South African pork producers (Dreyer 2016). This has a direct impact on the market price of pork. Because Piggery A is a price taker, it results in the profitability of Piggery A being negatively affected, as also informed by the third factor. Dreyer (2016) documented the farming operation of Piggery M, which had 20000 sows in production at the time of filming, with $1000+$ employees in service, and was building another production plant for an additional 9000 sows. This mega-farming operation is described as a vertically integrated supply chain against which Piggery A cannot compete. Besides the piggery, this mega-farming operation has a dairy operation with 9000 cows milked twice daily. The cows feed off a pasture system, meaning pasture is cultivated. The dairy supplies a cheese factory with the required milk to produce its products and, in return, the dairy provides the piggery with whey, which serves as an important component of the feed mixture of the pork production operation. The pork production operation, in turn, supplies effluent that provides the necessary nutrients to cultivate lush pasture for the dairy operation. At the time of filming, the farming operation started producing electricity from the methane harvested from the piggery's manure. All this provides for a competitive advantage which would make it difficult for average commercial farmers to compete against and still be profitable.

\section{Piggery A's losses}

The decrease in the price of pork was evident from the management information of Piggery A. This had an extremely negative impact on its profitability. Although Piggery A has an integrated farming operation that can be seen as naturally sustainable, it remains confined within the farming operation itself and therefore does not have the same economic leverage that an integrated supply chain such as Piggery $M$ has. Owner A indicated that if Piggery A was to become profitable again, it would have to widen its range of services to include value-adding activities such as an abattoir where the production of the piggery can be processed to be sold on the market at a premium.

The next important factor that Piggery A needs to turn around in profitability is the production size. With less than 600 sows, Piggery A does not command the economies of scale which would allude to any advantage over other producers in terms of bargaining power with the abattoirs in the region. After consulting with Piggery A's banker as well as with a respected abattoir near Johannesburg, Owner A came to the conclusion that Piggery A would continue to make a loss given the economic circumstances in which it has to operate.

\section{South Africa's expected economic growth}

Owner A stated that various external sources of information informed him that the South African economy is expected to grow by close to $0 \%$. Statistics South Africa (StatsSA 2016) declared that the South African economy retracted by $1.2 \%$ in the first quarter of 2016, quarter-on-quarter, and grew by $0.6 \%$ in the second quarter of 2016 year-on-year. Given this weak growth recorded in the first semester of 2016 , coupled with the weak growth of $0.6 \%$ in the fourth quarter of 2015, year-on-year, it is not unreasonable for Owner A to expect the South African economy to grow by close to $0 \%$. 
In addition to the four main factors described above, an overarching factor to the decision to discontinue pork production is the advanced age of Owner A. Given that Piggery A is a sole proprietor business form, the age of Owner A precludes it from engaging in major capital projects which would take any given number of years to become productive and profitable. Principles within GMAPs inform this as well, given that Owner A is a key stakeholder and that the regulatory environment as well as key external stakeholders would have to be identified and engaged in this matter, which is what Owner A has done by consulting the banker and the abattoir.

The questions that remain are firstly whether or not GMAPs could have assisted Owner A with steering clear of this definitive decision by providing the information more timely with strategic options to turn the profitability of Piggery A around. Secondly, it could be asked whether or not GMAPs could have informed the decision earlier on, with strategic alternative options to consider for cash-generating activities which could harness the infrastructure already in place to avoid prolonged periods of internal losses. Both questions should be considered within a hypothetical context that GMAPs have been a known tool in the overall management accounting function, which is Piggery A.

The most prevalent GMAPs for Piggery A seem to be that of 'information that is relevant', with 'impact on value that is analysed' in the next order of dominance, followed lastly by 'communication that provides insight that is influential'.

\section{Summary of findings}

The decision to divest from the piggery operation has been unexpected, given the observation of sound business principles evident by the presence of GMAPs in the farming operation. The conclusion can therefore be made that GMAPs would, at best, provide the platform for Owner A to make an informed decision regarding continuation of the operation of Piggery A. Because the principles that were observed as being present in the farming operation were not assessed in terms of quality or scope, the question would arise as to the extent that GMAPs could have informed the decision to discontinue the production of pork at an earlier date to limit the losses made over the last 3 years. Another question would be whether GMAPs would have provided guidance to Owner A in terms of alternative options to replace the loss of cash generation capability through diversification, such as the acquisition of a herd of sheep for the production of lamb, or the acquisition of a herd of cattle for beef production. The answers would depend on the deployment of the principles throughout the farming operation and the participation of all key stakeholders of the farming operation, both internal and external, if they are identified and kept informed in this regard.

From this, it is evident that the most basic need of Piggery A in terms of management accounting is the production of management information in a decision-useful way. This is seen with information which Owner A reviews on a monthly basis, which includes financial and non-financial information and is produced by various internal stakeholders of the farming operation. Therefore, the most important principle of GMAPs for Piggery A is 'information is relevant' and 'impact on value is analysed', followed closely by 'communication provides insight that is influential'. Furthermore, the information that is gathered by the internal stakeholders must be analysed and presented in a similar fashion as is currently the practice, in order to provide for a platform to communicate with external stakeholders such as the banker and abattoirs.

\section{Concluding remarks}

The main objective of the article was to evaluate GMAPs in the sustainability of Piggery A. It was discovered that Piggery A has been operating since 1968 and is applying practices that can be argued to contribute towards a sustainable farming operation. It was also discovered that Piggery A was operated without debt until as recently as 2013. Owner A considered this to be a real measure of success which also alluded to his risk appetite being low. The conclusion was therefore made that Piggery A has been operating sustainably for 48 years. It was established through the diagnostic checklist and a process of 'crystallisation' that Piggery A engages in a large number of principles and practices measured with the diagnostic checklist. During the interview, it was discovered that Owner A took four main factors into consideration when making a decision to discontinue pork production. It can therefore be concluded that GMAPs that were displayed at Piggery A assisted with the sustainability of Piggery A and also supported Owner A's decision-making process regarding the future of the pork production part of the farming operation.

Even with the presence of GMAPs in the business, Piggery A was unable to profitably navigate the external forces that impacted the farming operation. These forces were summarised as being external economic factors in the form of the AGOA Trade Agreement with the USA, rivalry amongst competitors with the existence of mega farmers with farming operations using sophisticated and integrated supply chains and an unparalleled economies of scale, as well as the 'close to zero' growth of South Africa's economy. These factors led to internal profitability issues that were aggravated by the opportunity cost of consuming the highquality maize harvested from the farming operation's maize fields by the piggery, rather than selling it on the market at a profit. The strong presence of GMAPs in Piggery A contributed to the decision-making process that Owner A described.

Although the question could be asked as to whether or not Owner A could have made the decision to discontinue pork production earlier, had GMAPs been actively pursued as best practice, it might not be the correct question to contemplate. More appropriately, the question that has arisen from this case study is whether or not Owner A would have come to a 
decision to discontinue pork production in any case, had GMAPs not been present in Piggery A at all, or even nearly as strong as was the case.

As GMAPs were found in practice in Piggery A - a sole proprietor - supporting its sustainability, it could be generalised that GMAPs would be applicable to more complex business forms such as companies, trusts or closed corporations.

It is therefore recommended, based on the findings of this study, that all commercial farming operations should consider GMAPs as a tool to establish best practice in the support of decision-making that promotes sustainability of farming operations.

\section{Limitations and areas for future research}

The most prominent limitation of this study is based on the inherent limitations of case study research. This study gained an in-depth understanding of a specific phenomenon (Nieuwenhuis 2014), being Piggery A's farming operation. Piggery A operates as a sole proprietor which could be seen as a basic business form. As such, it could be argued that the findings of this study cannot be generalised to other more complex business forms. However, most commercial farming operations that operate within a sole proprietor business form can use GMAPs as a tool to enhance the quality of the decision-making processes.

Another limitation of this study is that it highly relied on information provided by the owner and the professional accountant of Piggery A to evaluate the presence of GMAPs in the farm.

This article leaves the following opportunities for further research:

1. The evaluation of GMAPs can be extended to megafarming operations that operate within legal entities such as companies.

2. The diagnostic checklist is designed to cater for corporates with separate management accounting functions. Qualitative research can be conducted to determine possible replacement questions for the parts that focus on matters such as the treasury function or external auditing.

3. The use of a Likert scale when answering the diagnostic checklist can be investigated to add further value to researchers' evaluation of GMAPs, making it possible to determine the extent to which GMAPs contribute towards the sustainability of a farming operation.

4. This study focused on a case where the farming operation had not been aware of the existence of the best practice highlighted by GMAPs. A study can be conducted on farming operations' performance before and after awareness has been cultivated to evaluate the economic contribution that GMAPs bring to the table.

\section{Acknowledgements}

The authors gratefully acknowledge the Chartered Institute of Management Accountants' (CIMA) Centre of Excellence South Africa and the National Research Foundation (NRF) for providing the financial support to carry out this study.

\section{Competing interests}

The authors declare that they have no financial or personal relationships which may have inappropriately influenced them in writing this article.

\section{Authors' contributions}

A.B.B. was the main researcher responsible for the project design, whereas S.L.M. made conceptual contributions and co-wrote the article.

\section{References}

Agri South Africa, 2015, Crime undermines development, Pretoria, viewed 22 July 2015, from http://www.agrisa.co.za/wp-content/uploads/2015/07/07-Misdaadskaad-21-Julie.pdf

Ariatti, C. \& Chasomeris, M., 2015, 'Agriculture and local economic development: A case study of uMshwathi', Journal of Economic and Financial Sciences 8(2), A case stud $432-455$.

Bibbey, F.J., 1995, 'The application of management accounting principles in the stonequarry industry', MCom dissertation, PU for CHE, Potchefstroom.

Brundtland, G.H., 1989, 'Global change and our common future', Environment 31(5), 16. https://doi.org/10.1080/00139157.1989.9928941

Bui, B. \& de Villiers, C., 2017, 'Business strategies and management accounting in response to climate change risk exposure and regulatory uncertainty', The British Accounting Review 49(1), 4-24. https://doi.org/10.1016/j.bar.2016.10.006

Chartered Institute of Management Accountants (CIMA), 2016, Joining the dots: Decision making for a new era, CIMA, London.

Chartered Institute of Management Accountants (CIMA) \& American Institute of Certified Public Accountants (AICPA), 2014, Global management accounting principles, CIMA \& AICPA, London.

Chartered Institute of Management Accountants (CIMA) \& American Institute of Certified Public Accountants (AICPA), 2015, Diagnostic checklist - Global management accounting principles, CIMA \& AICPA, London.

Chartered Institute of Management Accountants (CIMA), American Institute of Certified Public Accountants (AICPA) \& Chartered Professional Accountants of Canada (CPA), 2013, CGMA tools - Ten key elements to sustainable business practices in SMEs, CIMA, AICPA \& CPA, London.

Darroch, M., Lee, R. \& Ortmann, G., 2008, 'The economic impact of a rural land tax on selected commercial farms in KwaZulu-Natal, South Africa', South African Journal of Economic and Management Sciences 11(3), 372-387. https://doi.org/10.4102/ sajems.v11i3.465

Department of Agriculture, Forestry and Fisheries (DAFF), 2016, Abstract of agricultural statistics 2016, Government Printer, Pretoria.

Dignen, S., 2000, Reprint, Pearson Education Limited, Essex.

Dreyer, W., 2016, Megaboere, by Parrot, KykNET, Johannesburg. [Television]

Figge, F. \& Hahn, T., 2013, 'Value drivers of corporate eco-efficiency: Management accounting information for the efficient use of environmental resources', Management Accounting Research 24, 387-400. https://doi.org/10.1016/ j.mar.2013.06.009

Gan-Mor, S., Clark, R.L. \& Upchurch, B.L., 2007, 'Implement lateral position accuracy under RTK-GPS tractor guidance', Computers and Electronics in Agriculture 59(1), 31-38. https://doi.org/10.1016/j.compag.2007.04.008

Gimzauskiene, E. \& Valanciene, L., 2008, 'The changing role of management accounting systems towards value creation', Journal of Economic and Financial Sciences 2(1), 7-30.

Hamilton, M., 2006, 'Learn to be a price harvester, not a price taker', Southwest Farm Press 33(10), 34

Holloway, J.H., 2004, 'Bestuursrekeningkunde as basis vir ' $n$ inligtingstelsel vir opkomende appelprodusente: ' $n$ gevallestudie [Management accounting as basis for an information system for emerging apple producers: A case study]', MCom for an information system for emerging apple producer
dissertation, North-West University, Potchefstroom.

Joubert, M.L., 1996, 'Die toepassing van aktiwiteitsgebaseerde koste in die lugvaartbedryf: ' $n$ gevallestudie [The application of activity-based costing in the lugvaartbedryf: ' $\mathrm{n}$ gevallestudie [The application of activity-based costing in the
aviation industry: A case study]', MCom mini-dissertation, PU for CHE, Potchefstroom. 
King Committee, 2009, King code of governance principles for South Africa 2009 (King III), Institute of Directors Southern Africa, Johannesburg.

Konan, N.C., 2013, 'Problems encountered with the implementation of an activitybased costing system', MTech dissertation, Nelson Mandela Metropolitan University, Port Elizabeth.

Le Roux, A.W.G., 1982, "n Koste-en kosprysanalise van sultana-verbouing in die Oranjerivier-besproeiingsgebied [A cost- and cost price analysis of sultana cultivation in the Orange river irrigation area]', MCom mini-dissertation, PU for $\mathrm{CHE}$, Potchefstroom.

Lichfield, J., 2015, Striking French farmers block all access to tourist attraction Mon St Michel over deal 'broken by supermarkets', viewed 20 July 2015, from http:// www.independent.co.uk/news/world/europe/striking-french-farmers-block-allaccess-to-tourist-attraction-mont-st-michel-over-deal-broken-by-10402953 htm

Luft, J. \& Shields, M.D., 2003, 'Mapping management accounting: Graphics and guidelines for theory-consistent empirical research', Accounting, Organization and Society 28(2), 169-249. https://doi.org/10.1016/S0361-3682(02)00026-0

Masztalerz, M., 2014, 'Global management accounting principles-emperor's new clothes?', Prace Naukowe Uniwersytetu Ekonomicznego we Wrocławiu 345 57-65.

Middelberg, S.L., 2007, 'Application of management accounting principles in the bread industry: A case study', MCom mini-dissertation, North-West University, Potchefstroom.

Mokhema, T., 2015, 'SA farmers need more government help - Study', Bloomberg News, viewed 22 July 2015, from http://www.moneyweb.co.za/news/southafrica/sa-farmers-need-more-government-help-study/

Munzhelele, P., Oguttu, J., Fasanmi, O.G. \& Fasina, F.O., 2017, 'Production constraints of smallholder pig farms in agro-ecological zones of Mpumalanga, South Africa', Tropical Animal Health and Production 49(1), 63-69. https://doi.org/10.1007/ s11250-016-1158-7
Nieuwenhuis, J., 2014, 'Introducing qualitative research', in K. Maree (ed.), First steps in research, 14th edn., pp. 47-122, Van Schaik, Pretoria.

Nkosi, T., 2015, 'Nail-biting action has no place in agricultural policy-making', Agri 44(3), 121.

Reynolds, A. \& Van der Poll, H., 2015, 'ABC implementation in the Nelson Mandela Bay Metropole: How far should manufacturing organisations go?', Southern African Business Review 19(2), 118-136.

Rundora, R., Ziemerink, T. \& Oberholzer, M., 2013, 'Activity-based costing in small manufacturing firms: South African study', Journal of Applied Business Research 29(2), 485-498. https://doi.org/10.19030/jabr.v29i2.7652

Saayman, M.J.M. \& Middelberg, S.L., 2014, 'The effect of higher wages on production cost and mechanization: A South African maize sector study', Journal of Applied Business Research 30(2), 341-352. https://doi.org/10.19030/jabr.v30i2.8402

Savic, B., Vasiljevic, Z. \& Dordevic, D., 2014, 'Strategic cost management as instrument for improving competitiveness of agribusiness complex', Ekonomika Poljoprivrede 61(4), 1005-1020. https://doi.org/10.5937/ekoPolj1404005S

Schaltegger, S., 2011, 'Sustainability as a driver for corporate economic success: Consequences for the development of sustainability management control' Society and Economy 33(1), 15-28. https://doi.org/10.1556/SocEc.33.2011.1.4

Smith, N., 2014, 'First principles', Financial Management, April, p. 40.

Statistics South Africa (StatsSA), 2016, The economy - GDP, viewed 03 October 2016 , from http://www.statssa.gov.za/

Van der Linde, M., 2011, 'Embedding an activity driven operational accounting framework in a fertiliser company', MCom dissertation, North-West University, Potchefstroom.

Visser, J., 2015, 'Farm workers' minimum wage to jump 7,7\%', Farmers Weekly, 06 February, p. 22.

Yin, R.K., 2014, Case study research: Design and methods, 5th edn., Sage, London. 